\title{
Obituary
}

\section{P W Duchosal}

Professor Pierre Duchosal who died in Geneva on 24 April 1988 at the age of 82 was one of the world's leading cardiologists. He made important advances in clinical diagnosis, instrumentation, and organisation. His interest in techniques of investigation coupled with a practical and inventive mind led him to develop the first direct writing electrocardiograph at the age of only 23, which was followed by a multichannel recorder for phonocardiography. This heralded his mastery of cardiac auscultation and the invention with J Monti of the Didactaphone which allows simultaneous auscultation by groups of students using their own stethoscopes. This apparatus is installed in two London lecture theatres. He was also a pioneer of vector cardiography and with Sulzer he established the technique of spatial vectorial analysis. His eminence in research and teaching led to the establishment for him of the Chair of Cardiology at the Hôpital Cantonal which he occupied from 1953 to 1976 . He was deeply involved with the International Society of Cardiology being secretary general for some years and ultimately president. The Swiss Foundation of Cardiology was created by his initiative to further public education and to support young research workers. $\mathrm{He}$ was an honorary member of the British Cardiac Society.

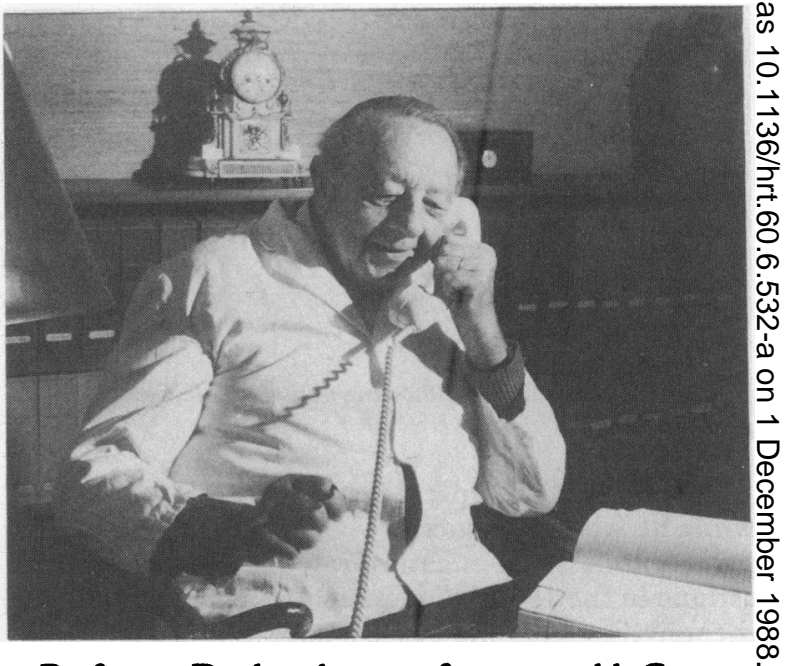

Professor Duchosal came from an old Geneva family and his early intention to become a violinist led to a continuing devotion to music with equal interests in archaeology and painting. He was a true humanist and a very warm hearted man whom it was always a pleasure to meet.

\section{Notices}

\section{British Cardiac Society}

The Annual General Meeting for 1989 will take place in Oxford on 6 and 7 April 1989, and the closing date for receipt of abstracts will be 6 January 1989 .

\section{Cardiac pacing}

The 4th European Symposium on Cardiac Pacing will take place in Stockholm on 28 to 31 May 1989 . Inquiries to Congrex, Box 5619, S-114 86 Stockholm, Sweden. 